\title{
Introducing...
}

\section{Social Philosophy}

\section{\& Policy}

Editor: Ellen Frankel Paul, Social Philosophy and Policy Center, Bowling Green State University

Associate Editors: Fred Miller, Jr. and Jeffrey Paul, Social Philosophy and Policy Center

Social Philosophy of Policy is an interdisciplinary journal with an emphasis on the philosophical underpinnings of enduring social policy debates.

The semi-annual issues are thematic in format, examining a specific area of concern with contributions from scholars in philosophy, economics, political science and law. While not primarily a journal of policy prescriptions, articles typically connect theory with practice.

Papers are submitted upon invitation from the Editors and represent a broad spectrum of political and philosophical views on a given theme. The editors, with the aid of a distinguished editorial board, seek contributions from well-known scholars as well as promising younger researchers.

The 1996 issues will be 'Community, Individual and the State' and 'Scientific Innovation, Philosophy, and Public Policy'.

\section{Subscription Information}

Social Pbilosopty and Policy is published twice a year in Winter and Summer.

Volume 13 in 1996: $£ 54$ for institutions; $£ 21$ for individuals; airmail costs $£ 10$ per year extra. ISSN 0265-0525.
"Social Philosophy of Policy is that rare journal which brings together the best in philosophy, politics, law, and economics. The distinguished author whom it publishes in its timely symposia produce works which are required reading both for specialists in these areas and for the general reader."

RICHARD ERSTEIN, UNIVERSTT Of CHICAGO

\section{Further Information}

$\square$ Please send me further information on Social Philosophy and Policy

Name

Address

I

1

1

Send your coupon to: Journals Marketing Department, Cambridge University Press, FREEPOST*, The Edinburgh

Building, Cambridge CB2 2BR, UK (" no postage stamp necessary if posted in UK) Tel: (0) 1223325806

Fax (0) 1223315052

Email: journals_marketingecaup.cam.aculk

CAMBRIDGE I. UNIVERSITY PRESS 


\title{
REVUE INTERNATIONALE DE PHILOSOPHIE
}

\author{
Editor: Michel MEYER \\ Université de Bruxelles, C.P. 188 \\ 50, avenue F.D. Roosevelt - 1050 Brussels, Belgium
}

Each number is devoted to a particular movement, a particular philosopher, or a particular problem.

We publish 4 issues annually. Articles are written in English, French, German, or Italian.

Our last issue was devoted to Descartes.

Articles by: Jaakko Hintikka, Cogito, ergo quis est? - Michel Meyer, The Problematological Interpretation of the Cogito - Jean-Marie Beyssade, La Théorie Cartésienne de la Substance - Georges Moyal, Magiciens, Doubters and Perverts - Jean-Luc Marion, A propos de Suarez et Descartes - Dalia Judovitz, La Vision, la Représentation et la Technologie chez Descartes - Nicolas Grimaldi, Le Temps chez Descartes - John Cottingham, Cartesian Ethics : Reason and The Passions - Comptes rendus: Robert F. Barsky, Constructing a Productive Other: Discourse Theory and the Convention Refugee Hearing (Peter Hitchcock) - Jean-Thomas Normand, Taine et la Critique Scientifique (Angèle Kremer-Marietti) - Lygia Négrier-Dumont et Stanislas Tzitzis, Criminologie de l'Acte et Philosophie Pénale. De l'Ontologie Criminelle des Anciens à la Victimologie Appliquée des Modernes (Angèle Kremer-Marietti) - Benoît Timmermans, La Résolution des Problèmes de Descartes à Kant. L'Analyse à l'Âge de la Révolution Scientifique (Angèle Kremer-Marietti) - B. Waldenfels, Antwortregister (Michel Meyer).

Coming numbers: Contemporary Trends in Argument Theory, Le Premier Romantisme Allemand, Derrida, Esthétique, Saint Thomas d'Aquin. 


\section{Information for Authors}

Prospective authors should send their contributions, typed and doublespaced on quarto or A4 paper, to the Editor, Professor Anthony O'Hear, Royal Institute of Philosophy, 14 Gordon Square, London WC1H 0AG. They should retain a second copy for the purpose of checking proofs. When an article has been accepted for publication, the author is strongly encouraged to send a copy of the final version on computer disk (Apple Macintosh or IBM compatible PC) together with the hard copy typescript, giving details of the wordprocessing software used (Microsoft Word, Word or Word Perfect). However, the publisher reserves the right to typeset material by conventional means if an author's disk proves unsatisfactory. Authors should observe the conventions of the journal. The Editor may alter manuscripts wherever necessary to make them conform to the stylistic and bibliographical conventions of the journal. Single quotation marks should be used except where there is a quotation within another. The titles of books and journals should be underlined (i.e. to be printed in italics), as should foreign words. Titles of articles should be in single quotation marks.

Notes and references will be printed as footnotes and should be typed (double-spacing) on a separate sheet, numbered consecutively. They should be referred to in the text by superscripts. Citations should be as follows:

H. B. Acton, The Philosophy of Punishment (London: Macmillan, 1969), 192-198.

2 R. S. Downie and Elizabeth Telfer, 'Autonomy', Philosophy 46, No. 178 (October 1971), 295.

'Op. cit. note 1, 101-112.

'W. C. Wimsatt, 'Some Problems with the Concept of Feedback', Boston Studies in the Philosophy of Science, VIII, R. C. Buck and R. S. Cohen (eds.) (Dordrecht: D. Reidel, 1971), 242.

The return of contributions cannot be guaranteed unless they are accompanied by stamps, or in the case of contributions from abroad, by international coupons, to cover postage. A self-addressed envelope should also be enclosed.

Only corrections of printer's errors can be allowed in proofs. Authors are therefore asked to send any alterations or additions to Professor O'Hear as soon as possible after receiving his letter of acceptance.

Authors of articles, discussion papers and review articles will receive twenty-five offprints free of charge. Additional offprints can be ordered when proofs are returned by arrangement with the Institute.

Books for review should be sent to the Editor at the Institute and not to Cambridge University Press. Publishers are asked to note that nonphilosophical works are not reviewed in Philosophy.

Authors' corrected proofs should be sent to Professor O'Hear at Royal Institute of Philosophy, 14 Gordon Square, London, WC1H 0AG. All other correspondence should also be addressed to the Institute.

\section{CAMBRIDGE UNIVERSITY PRESS}

The Pitt Building, Trumpington Street, Cambridge CB2 1RP

40 West 20th Street, New York, NY 10011-4211, USA

10 Stamford Road, Oakleigh, Melbourne 3166, Australia 


\section{Philosophy}

VOLUME 71 NO 276 APRIL 1996

Editorial: Philosophy and Children

Axiological Realism - JOEL J. KUPPERMAN

The Concept of a University - D. Iv. HAMLYN

McDowell's Kant: Mind and World- GRAHAM BIRD

The Causal Theory of Veridical Hallucinations - SEAN WILKIE

Inquiry in the Arts and Sciences - JAMES o. YOUNG 255

Cambridge Philosophers V: G. E. Moore - THOMAS BALDWIN

Discussion

On Coming Home to (Metaphysical) Realism - JOHN HALDANE Anscombe on the Tractatus - PALL O'GRADY

New Books

Reviews

Booknotes

Books Received

Notebook

(c) The Royal Institute of Philosophy 1996

Typeset by Michael Heath Limited, Reigate, Surrey

Printed in Great Britain bv the University Press, Cambridge 